\title{
Chlorophyll content, photosynthetic efficiency and genetic markers in two sour cherry (Prunus cerasus L.) genotypes under drought stress
}

\author{
Marija Viljevac ${ }^{1 *}$, Krunoslav Dugalić ${ }^{1}$, Ines Mihaljević ${ }^{1}$, Domagoj Šimić ${ }^{1}$, \\ REZICA SUdAR ${ }^{1}$, ZORICA JURKOVIĆc ${ }^{1,2}$, HRVOJE LEPEDUŠ ${ }^{3}$ \\ ${ }^{1}$ Agricultural Institute Osijek, Južno predgrađe 17, HR-31000 Osijek, Croatia \\ ${ }^{2}$ Croatian Food Agency, I. Gundulića 36b, HR-31000 Osijek, Croatia \\ ${ }^{3}$ Faculty of Humanities and Social Sciences, J.J. Strossmayer University of Osijek, \\ L. Jägera 9, HR-31000 Osijek, Croatia
}

\begin{abstract}
Drought is a limiting factor in fruit production today. Identification of sour cherry genotypes tolerant to drought will enable the sustainability of fruit production. The aim of our study was to select sour cherry genotypes according to their genetic background as well as drought tolerance and investigate possible mechanisms of drought tolerance through the changes in photosynthetic apparatus (i.e. photosynthetic pigment content) and photosynthesis process assessed through the chlorophyll fluorescence transient. All of them together with molecular markers (SSRs and AFLPs), relative water content (RWC) as indicator of plant water status distinguish two genotypes (Kelleris 16 and OS), which are the opposite in regards to drought tolerance. Down-regulation of photosynthesis in drought-treated Kelleris 16 plants was seen as changes in antenna complexes of PSII (decreased total chlorophylls content $(a+b)$ and chlorophylls ratio $(a / b))$. Despite unchanged maximum quantum yield of PSII in drought-treated leaves of genotype OS, overall photosynthetic performance expressed as $\mathrm{PI}_{\mathrm{ABS}}$ was down-regulated in both investigated genotypes. However, decrement of $\mathrm{PI}_{\mathrm{ABS}}$ was much pronounced in genotype Kelleris 16, mainly because of changes in a certain fraction of RCs, which become dissipative centres, seen as increase in $\mathrm{ABS} / \mathrm{RC}$ and $\mathrm{DI}_{0} / \mathrm{RC}$, in order to avoid photooxidative damage of photosynthetic apparatus. Also, electron transport, seen as decrease in $\mathrm{ET}_{0} /\left(\mathrm{TR}_{0}-\mathrm{ET}_{0}\right)$ and $\mathrm{ET}_{0} / \mathrm{RC}$, was impaired which lead to impaired $\mathrm{CO}_{2}$ fixation and photosynthesis. The described changes in the functioning of photosynthetic apparatus in drought-treated plants of Kelleris 16 constitute the main distinction between the two investigated genotypes regarding drought adaptation mechanisms.
\end{abstract}

Key words: chlorophyll fluorescence, drought tolerance, genetic variability, leaf water content, photosynthetic pigments, Prunus cerasus, sour cherry

* Corresponding author, e-mail: marija.viljevac@poljinos.hr

Copyright $^{\circledR} 2013$ by Acta Botanica Croatica, the Faculty of Science, University of Zagreb. All rights reserved. 


\begin{abstract}
Abbreviations: ABS/RC - absorption per active reaction centre; AFLP - amplified fragment length polymorphism; Chl $\boldsymbol{a}$ - chlorophyll $a$; Chl $\boldsymbol{b}$ - chlorophyll $\boldsymbol{b}$; Chl $\boldsymbol{a}+\boldsymbol{b}$ - total chlorophylls; DW - dry weight; CTAB - cetyl trimethylammonium bromide; $\mathbf{D I} \mathbf{I}_{\mathbf{0}} / \mathbf{R C}$ dissipation per active reaction centre; $\mathbf{E T}_{\mathbf{0}} / \mathbf{R C}$ - electron transport per active reaction centre; $\mathbf{E T}_{\mathbf{0}} /\left(\mathbf{T R}_{\mathbf{0}} / \mathbf{E T}_{\mathbf{0}}\right)$ - electron transport beyond $\mathrm{Q}_{\mathrm{A}}{ }^{-} ; \mathbf{F}_{\mathrm{v}} / \mathbf{F}_{\mathbf{m}}-$ maximum quantum yield of photosystem II; FW - fresh weight; LHC - light harvesting complex; OJIP test - chlorophyll $a$ fluorescence transient measurement; PCR - polymerase chain reaction; $\mathbf{P I}_{\mathbf{A B S}}-$ photosynthetic performance index; PSII - photosystem II; PVP - polyvinylpyrrolidone; $\mathbf{Q}_{\mathbf{A}}$ - primary plastoquinon acceptor; $\mathbf{Q}_{\mathbf{B}}-$ secondary plastoquinon acceptor; $\mathbf{R A P D}$ - random amplified polymorphic DNA; RC/ABS - density of reaction centers on chlorophyll basis; RFLP - restriction fragment length polymorphism; RWC relative water content; SSR - simple sequence repeats; $\mathbf{T R}_{\mathbf{0}} / \mathbf{D I}_{\mathbf{0}}$ - flux ratio trapping per dissipation; $\mathbf{T R}_{\mathbf{0}} / \mathbf{R C}$ trapping per active reaction centre; TW - turgid weight; UPGMA - unweighted pair group method with arithmetic mean
\end{abstract}

\title{
Introduction
}

The sour cherry (Prunus cerasus L.) is a significantly represented fruit in Croatian orchards, growing on 2400 ha in 2010. (FAo Statistical Databases 2011). Phenological, pomological and chemical variability was found within the population (PUŠKAR 2005). Therefore, it is necessary to perform clonal selection in order to isolate and characterize genotypes with good agronomic traits in order to create seedlings that will ensure uniformity and quality of sour cherry plantations. While phenological, pomological and chemical properties of individual sour cherry genotypes are under the influence of environmental factors, it is necessary to conduct the analysis at the genome level. Among the many molecular markers, SSR and AFLP markers have proved to be reliable methods for determination of genetic variability in most species of the genus Prunus (DIRLEWANGER et al. 2002, HormazA 2002, PEDERSEN 2006).

Since drought is one of the limiting factors in fruit production today, identification of sour cherry genotypes tolerant to drought will enable the sustainability of fruit production with respect to climate change in the future. Reduced water content and leaf water potential, loss of turgor and stomata closure ultimately lead to arrest of photosynthesis, metabolic disorders and plant death (JALEEL et al. 2009). Leaf relative water content (RWC) is a good criterion for the primary selection of wheat and tomato genotypes tolerant and sensitive to drought (RAmPINO et al. 2006, SÁNCHEZ-RodRíGuEZ et al. 2010). Also, RWC is better indicator of plant water status than water potential as it is associated with cell volume and precisely shows the balance between the absorbed and transpirated water (ROSALES-SERNAet al. 2004, HASSANZADEH et al. 2009).

Efficiency of the photosynthetic apparatus in response to drought was studied in many plant species (CLAVEL et al. 2006, CHRISTEN et al. 2007). The measurement of chlorophyll fluorescence is a method commonly used to study photosynthetic efficiency (MAXWELL and JOHNSON 2000). Measurement of the chlorophyll fluorescence transient, followed by OJIP-test, gives information on the functioning of the photosynthetic apparatus through parameters describing the absorption of photons, trapping of excitons, electron transport and energy dissipation in both stressful and in optimal conditions for plants (STRASSER et al. 2004). FORCE et al. (2003) have shown the advantage of the usage of the OJIP test in the evaluation 
of PSII efficiency, especially of the index of photosynthetic performance ( $\left.\mathrm{PI}_{\mathrm{ABS}}\right)$, since it provides information on overall energy flow through the PSII.

Photosynthetic pigments, especially chlorophyll $a$ and $b$, have a significant role in the process of photosynthesis because they are responsible for the absorption of light and transfer excitation energy to the chlorophyll molecules of reaction centres. In drought, photosynthetic pigment content decreases from optimal conditions in many plant species. Plants reduce photosynthetic pigment content in dry periods because this is a mechanism for the prevention of photosynthetic apparatus damage by allowing less light to be absorbed (Kauser et al. 2006, AbDalla and El-Koshiban 2007).

The aim of our study was to select different sour cherry genotypes according to their genetic background as well as drought tolerance. We hypothesized that genotypes with opposite reactions to drought, based on leaf RWC, have different mechanisms of adaptation. In order to investigate changes in PSII photochemistry of sour cherry genotypes in response to drought, two sour cherry genotypes with opposite reactions to drought were chosen according to their RWC for further studies of photosynthetic features through the photosynthetic pigments contents and chlorophyll fluorescence.

\section{Material and methods}

\section{Plant material}

Seven different sour cherry genotypes (genotypes Kelleris 16-KEL 16, Maraska-MA, Cigany - CG and Oblačinska represented with four genotypes OS, BOR, 18 and D6) were analyzed in this study. Plant material was obtained from Tovljač Orchard of Agricultural Institute Osijek. Young leaves for DNA analysis were picked in the spring of 2007 and stored at $-80{ }^{\circ} \mathrm{C}$ and lyophilized. Physiological experiments were performed on micropropagated seedlings produced in vitro by meristem isolation from axillary buds of same genotypes as DNA analysis.

\section{Photosynthetic efficiency under drought stress - greenhouse experiment}

An experiment was set up in a greenhouse of the Agricultural Institute Osijek during June 2011. Uniform two-year old in vitro propagated sour cherry plants in pots $(\sim 1.2 \mathrm{~L}$ of Floradure supstrate, Floragard, France) were selected randomly and placed on three movable tables with automatic irrigation systems in greenhouse. Ten plants of each genotype were placed on one table and served as controls. Control plants were treated with the optimal amount of water every other day according to optimized propagation process. Another ten plants of each genotype were placed on the other two tables (two identical experiments). These plants were exposed to drought stress due to lack of water. Within 10 days of the experiment, greenhouse daily temperatures were reaching up to $35^{\circ} \mathrm{C}$ while humidity varied from around $75 \%$ in the morning to $35-40 \%$ during a day. These conditions led to the complete desiccation and decay of plants exposed to water deficiency i.e. drought stress.

\section{Molecular markers analysis}

DNA extraction: Immediately before DNA extraction, lyophilized tissue was ground in an oscillatory mill and $40 \mathrm{mg}$ of sample was used for DNA extraction conducted by CTAB 
method (DOYLE and DoYLE 1987) slightly modified by the addition of $4 \%$ PVP to the extraction buffer. The DNA quality and quantity was double checked by band confrontation with $\lambda$ DNA on $1 \%$ agarose gels and by spectrophotometer (Biophotometer, Eppendorf, Germany). Original extracts of genomic DNA were diluted to a final working solution of 50

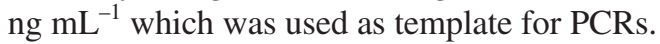

\section{Microsatellite analysis}

The twelve SSR primer pairs used for PCR amplification, previously described by CANTINI et al. (2001) and ClARKE and ToButT (2003), were provided by Metabion (Germany). PCR amplification for SSR analysis was carried out in $15 \mu \mathrm{L}$ of the reaction mix containing $50 \mathrm{ng}$ of template DNA, PCR buffer (10 mM Tris-HCl, $50 \mathrm{mM} \mathrm{KCl,} \mathrm{pH} \mathrm{8.3),} 0.2$ $\mu \mathrm{M}$ of each primer fluorescently labelled with Cy5, $0.2 \mathrm{mM}$ of each dNTP, $1.5 \mathrm{mM} \mathrm{MgCl}$, and 0.25 U of Taq DNA polymerase (Applied Biosystems, USA). The DNA was amplified in GeneAmp PCR System 2700 (Applied Biosystems, USA). »Touchdown « PCR conditions were used: $94{ }^{\circ} \mathrm{C}$ for $5 \mathrm{~min}$ followed by 10 cycles of $94{ }^{\circ} \mathrm{C}$ for $30 \mathrm{~s}, 60{ }^{\circ} \mathrm{C}$ for $45 \mathrm{~s}(-0.5$ ${ }^{\circ} \mathrm{C}$ per cycle), $72{ }^{\circ} \mathrm{C}$ for $1 \mathrm{~min}$ and then 25 cycles of $94{ }^{\circ} \mathrm{C}$ for $30 \mathrm{~s}, 55^{\circ} \mathrm{C}$ for $45 \mathrm{~s}, 72{ }^{\circ} \mathrm{C}$ for 1 min with an elongation step of $72{ }^{\circ} \mathrm{C}$ for $5 \mathrm{~min}$.

\section{AFLP assay}

AFLP reactions were performed as described by VOS et al. (1995) using EcoR I (5'-GACTGCGTACCAATTC-3') and MseI (5'-GATGAGTCCTGAGTAA-3') primers with one selective base in pre-amplification (E-A and M-C) and with three selective bases fluorescently labelled with Cy5 in amplification (E-AAA/M-CTT; E-AAA/M-CCT; E-ACT/ MCAT; E-ACT/M-CAG; E-ACA/M-CAA; E-ACA/M-CAC; E-ACA/M-CAT; E-ACA/M-CTA; E-ACA/M-CTC; E-ACA/M-CTG).

\section{Separation and visualisation of SSR and AFLP products}

Amplification products were separated on a $0.5 \mathrm{~mm}$ thick and 6 or $7.5 \%$ polyacrylamide denaturing gel (for SSRs and AFLPs, respectively), containing $7 \mathrm{M}$ urea. Electrophoresis was performed using an automated ALFexpress DNA sequencing system (Amersham Biosciences). Separation was done at $1200 \mathrm{~V}, 40 \mathrm{~mA}$, and $50 \mathrm{~W}$ for $360 \mathrm{~min}$ at $50{ }^{\circ} \mathrm{C}$. Fluorescence signals were collected every $1 \mathrm{~s}$ and stored in a computer. A fluorescence labelled molecular marker size (Cy5 Sizer 50-500; Pharmacia Biotech, Sweden) comprising 10 fragments in the size range of 50 to $500 \mathrm{bp}$ was used as an external size marker. For SSRs an additional two internal standards $(50,115,250$ or 334 bp) were used depending on the size of the expected SSRs. Amplified SSR and AFLP markers were then analysed using the software package AlleleLinks (Pharmacia Biotech, Sweden).

\section{Data analysis of molecular markers}

Only strong markers were scored as binary data, either with presence (1) or absence (0). All calculations were performed by NTSYSpc 2.1 software (Exeter Software Co., New York). The genetic similarity among genotypes was calculated using Dice's coefficient (DICE 1945) for both types of markers. Comparison between SSR and AFLP matrices was 
estimated by Mantel's test (MANTEL 1967), with which matrix comparison analysis was performed. Because of the high correlation between the matrices $(r=0.878)$, cluster analysis was generated from the similarity matrix of both SSRs and AFLPs data, by the unweighted pair group method, using an arithmetic averages (UPGMA) algorithm.

\section{Relative water content}

Every two days, leaf RWC was measured in control and stressed plants. Fully expanded leaves were excised and fresh weight $(\mathrm{FW})$ was immediately recorded. Leaves were then soaked for $24 \mathrm{~h}$ in distilled water at $8{ }^{\circ} \mathrm{C}$ in the dark, and the turgid weight (TW) was recorded. After drying for $24 \mathrm{~h}$ at $80^{\circ} \mathrm{C}$ total dry weight (DW) was recorded. RWC was calculated according to the formula: RWC $(\%)=(\mathrm{FW}-\mathrm{DW}) /(\mathrm{TW}-\mathrm{DW}) \times 100$. According to RWC analysis, genotypes with opposite reactions to drought would be identified and taken for further investigations.

\section{Chlorophyll $a$ fluorescence transient}

Chlorophyll fluorescence transient was measured on the eighth day of the experiment. It was induced by applying a pulse of saturating red light (peak at $650 \mathrm{~nm}, 3000 \mu \mathrm{mol} \mathrm{m}{ }^{-2} \mathrm{~s}^{-1}$ ) to leaves dark-adapted for $30 \mathrm{~min}$ before measurements. Changes in fluorescence were measured using Plant Efficiency Analyser (PEA, Hansatech, UK) for 1s, starting from $50 \mu \mathrm{s}$ after onset of illumination. During the first $2 \mathrm{~ms}$, changes were recorded every $10 \mu \mathrm{s}$ and every $1 \mathrm{~ms}$ afterward. The obtained data were used in the OJIP test in order to calculate several biophysical parameters of PSII functioning previously described by STRASSER et al. (2004).

\section{Determination of photosynthetic pigments concentration}

Concentrations of photosynthetic leaf pigments were measured on the eighth day of the experiment. Photosynthetic pigments were extracted from about $0.1 \mathrm{~g}$ of liquid-nitrogen-powdered leaves with ice-cold absolute acetone in the presence of magnesium hydroxide carbonate. Chlorophyll $a(\mathrm{Chl} a$ ) and chlorophyll $b(\mathrm{Chl} b)$ per dry weight of tissue (DW) were determined spectrophotometrically (Specord 200 Analytic Jena) at 470, 644.8 and $661.6 \mathrm{~nm}$ and total chlorophyll $(\mathrm{Chl} a+b)$ and chlorophyll $a / b$ ratio were calculated (LiCHTENTHALER 1987).

\section{Statistical analysis}

The results of the RWC were presented as adendrogram made by a single linkage method on the basis of Euclidean distances (CESAR et al. 2008, PEDISIĆ et al. 2010) calculated from parameter difference between control and drought treatment during ten days of experiment. Data on OJIP parameters and photosynthetic pigment concentrations measured in control and drought treated plants were subjected to $t$-test. Differences were considered significant at $\mathrm{p} \leq 0.05$. All statistical analyses were performed by Statistica 7.1. (StatSoft, Inc. 2005, USA). 


\section{Results}

The cluster analysis conducted based on the SSR and AFLP data revealed two main groups on dendrogram (Fig. 1). One of the groups (group 1) included only one genotype, Kelleris 16 from a Danish breeding program. The second group which is further divided

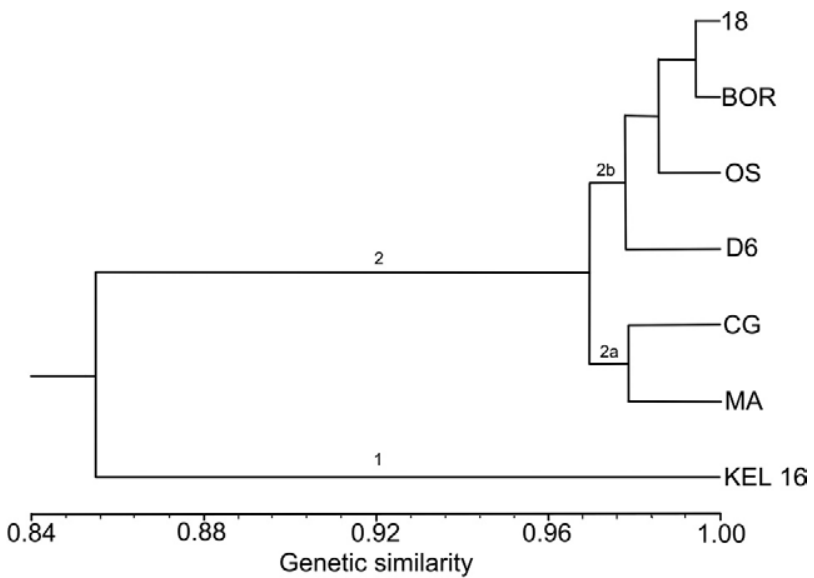

Fig. 1. Dendrogram based on genetic similarity from SSR and AFLP markers.

into two major subgroups ( $2 \mathrm{a}$ and $2 \mathrm{~b}$ ) contained the remaining analyzed genotypes with a very high coefficient of genetic similarity $(>0.96)$. Subgroup $2 \mathrm{a}$ included genotypes Maraska and Cigany, while subgroup $2 \mathrm{~b}$ included all investigated genotypes of genotype Oblačinska (OS, 18, D6, BOR). The dendrogram, based on Euclidean distances calculated from RWC difference between control and drought treatment during ten days of experiment (Fig. 2) is constituted by four main groups. The results, according to the grouping of genotypes, suggest that genotypes Kelleris 16 and OS have the opposite responses to drought, i.e. drought tolerance with genotype Kelleris 16 as less and genotype OS as more tolerant.

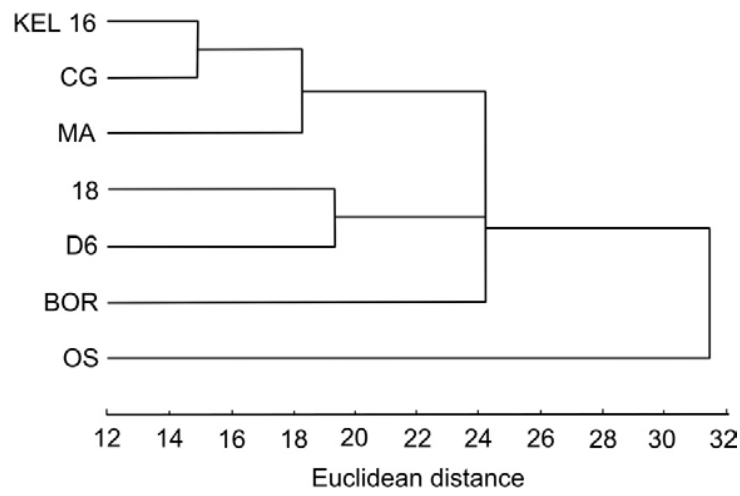

Fig. 2. Dendrogram based on Euclidean distances calculated from RWC difference between control and drought treatment during ten days of experiment. 
Drought stress down-regulated the photochemical efficiency of PSII (Figs. 3, 4; Tab. 1). Maximum quantum yield of PSII ( $\left.\mathrm{F}_{\mathrm{v}} / \mathrm{F}_{\mathrm{m}}\right)$ in leaves of genotype Kelleris 16 (Fig. 3A; Tab. 2) in drought treatment was low compared to control with values 0.38 in drought and 0.84 in control treatment. Values of $\mathrm{F}_{\mathrm{v}} / \mathrm{F}_{\mathrm{m}}$ in leaves of genotype OS were 0.82 and 0.81 in control and drought treatment, respectively. Performance index $\left(\mathrm{PI}_{\mathrm{ABS}}\right)$ was also decreased in drought-treated leaves (Fig. 3B; Tab. 2) of both investigated genotypes. The values of $\mathrm{PI}_{\mathrm{ABS}}$ in genotypes Kelleris 16 and OS were 0.07 and 1.62, respectively, in drought-treated leaves. In control plants the values of $\mathrm{PI}_{\mathrm{ABS}}$ were 3.09 and 2.24, in genotypes Kelleris 16 and $\mathrm{OS}$, respectively.

Tab. 1. Mean values ( \pm standard deviation) of performance index components on the $8^{\text {th }}$ day of the experiment in control and drought-treated leaves of genotypes Kelleris 16 and OS.

\begin{tabular}{lccccc}
\hline \multirow{2}{*}{$\begin{array}{c}\text { Genotype } \\
\text { Treatment }\end{array}$} & \multicolumn{2}{c}{ Kelleris 16 } & & \multicolumn{2}{c}{ OS } \\
\cline { 2 - 3 } \cline { 5 - 6 } \cline { 5 - 6 } & Control & Drought & & Control & Drought \\
\hline $\mathrm{RR}_{0} / \mathrm{DI}_{0}$ & $0.47 \pm 0.02$ & $0.20 \pm 0.08$ & & $0.43 \pm 0.02$ & $0.40 \pm 0.01$ \\
$\mathrm{ET}_{0} /\left(\mathrm{TR}_{0}-\mathrm{ET}_{0}\right)$ & $1.27 \pm 0.20$ & $0.44 \pm 0.09$ & & $1.11 \pm 0.18$ & $0.95 \pm 0.12$ \\
\hline
\end{tabular}

Tab. 2. $t$-value and the probability levels in the $t$-test for maximum quantum yield of PSII $\left(\mathrm{F}_{\mathrm{v}} / \mathrm{F}_{\mathrm{m}}\right)$, performance index $\left(\mathrm{PI}_{\mathrm{ABS}}\right)$ and components of $\mathrm{PI}_{\mathrm{ABS}}$ measured on the $8^{\text {th }}$ day of the experiment in control and drought-treated leaves of genotypes Kelleris 16 and OS. Significance level is marked at $\mathrm{p} \leq 0.05(*), 0.01(* *)$ and $0.001(* * *)$. ns - no significance.

\begin{tabular}{lrrrrr}
\hline \multirow{2}{*}{$\begin{array}{c}\text { Genotype } / \\
\text { parameter }\end{array}$} & \multicolumn{2}{c}{ Kelleris 16} & & \multicolumn{2}{c}{ OS } \\
\cline { 2 - 3 } \cline { 5 - 6 } $\mathrm{F}_{\mathrm{v}} / \mathrm{F}_{\mathrm{m}}$ & $\mathrm{t}$ & $\mathrm{p}(\mathrm{t})$ & & $\mathrm{t}$ & $\mathrm{p}(\mathrm{t})$ \\
$\mathrm{PI}_{\mathrm{ABS}}$ & 6.47 & $* * *$ & & 1.57 & $\mathrm{~ns}$ \\
$\mathrm{RC} / \mathrm{ABS}$ & 12.23 & $* * *$ & & 2.57 & $*$ \\
$\mathrm{TR}_{0} / \mathrm{DI}_{0}$ & 8.94 & $* * *$ & & 4.17 & $* * *$ \\
$\mathrm{ET}_{0} /\left(\mathrm{TR}_{0}-\mathrm{ET}_{0}\right)$ & 15.54 & $* * *$ & & 1.49 & $\mathrm{~ns}$ \\
\hline
\end{tabular}

A

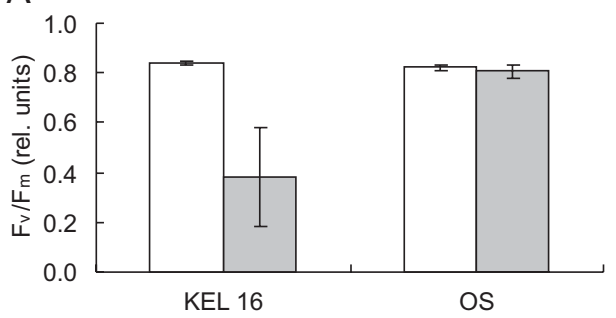

B

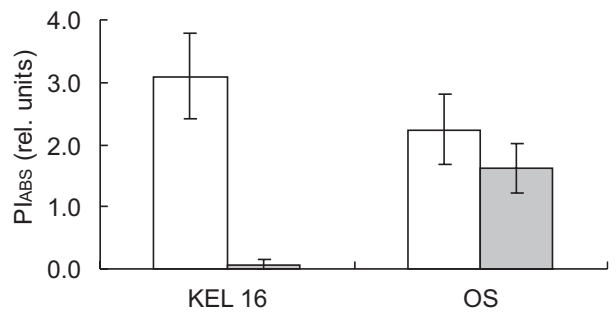

Fig. 3. Maximum quantum yield of PSII $-F_{v} / F_{m}$ (a) and performance index $-\mathrm{PI}_{\mathrm{ABS}}$ (b) in leaves of sour cherry genotypes Kelleris 16 and OS (control treatment - white columns, drought treatment - grey columns) on the $8^{\text {th }}$ day of the experiment. Vertical bars indicate \pm standard deviation. 
Values of performance index components (Tab. 1), such as density of reaction centres on chlorophyll basis $(\mathrm{RC} / \mathrm{ABS})$, ratio of trapping and dissipation fluxes $\left(\mathrm{TR}_{0} / \mathrm{DI}_{0}\right)$ and efficiency of the conversion of excitation energy to electron transport $\left(\mathrm{ET}_{0} /\left(\mathrm{TR}_{0}-\mathrm{ET}_{0}\right)\right.$, in leaves of drought and control treatment revealed that drought-treated leaves of genotype Kelleris 16 had significantly lower values $(\mathrm{p}<0.001)$ of all $\mathrm{PI}_{\mathrm{ABS}}$ components than control leaves (Tab. 2), while drought stress had a significant effect only on decrease of parameter $\mathrm{RC} / \mathrm{ABS}$ in drought-treated leaves of genotype OS compared to control leaves.

Mean values and significant differences between drought and control treatment leaves according to $t$-test for parameters that describe specific fluxes or specific activities per active reaction centre areshown in Fig. 4 and Tab. 3, respectively. Parameters describing ab-
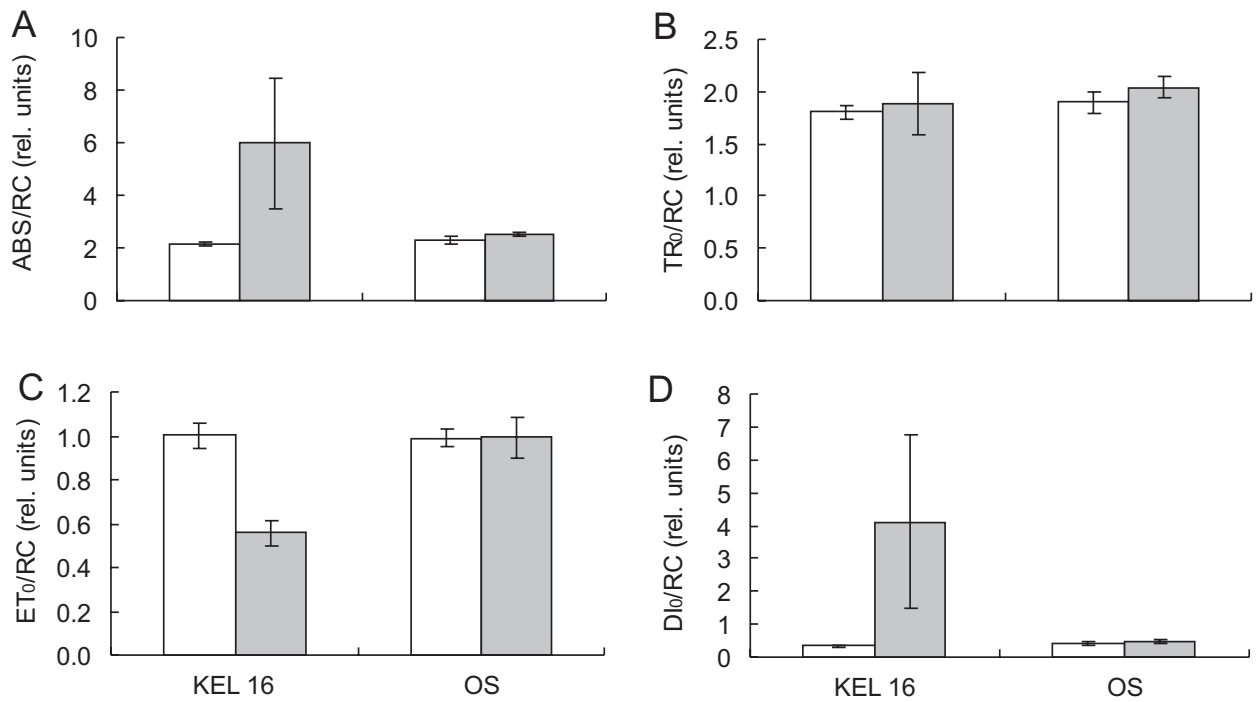

Fig. 4. Specific fluxes or specific activities per active reaction centre in leaves of sour cherry genotypes Kelleris 16 and OS on the $8^{\text {th }}$ day of the experiment (control treatment - white columns, drought treatment - grey columns): a) $\mathrm{ABS} / \mathrm{RC}$, b) $\mathrm{TR}_{0} / \mathrm{RC}, \mathrm{c}$ ) $\mathrm{ET}_{0} / \mathrm{RC}, \mathrm{d}$ ) $\mathrm{DI}_{0} / \mathrm{RC}$. Vertical bars indicate \pm standard deviation.

Tab. 3. $t$-value and the probability levels in the $t$-test for specific fluxes or specific activities per active reaction centre measured onf the $8^{\text {th }}$ day of the experiment in control and drought-treated leaves of genotypes Kelleris 16 and OS. Significance level is marked at $\mathrm{p} \leq 0.05(*), 0.01(* *)$ and $0.001(* * *)$. ns - no significance.

\begin{tabular}{lccccc}
\hline \multirow{2}{*}{$\begin{array}{c}\text { Genotype } / \\
\text { parameter }\end{array}$} & $\mathrm{t}$ & $\mathrm{p}(\mathrm{t})$ & & $\mathrm{c}$ & $\mathrm{OS}$ \\
\cline { 2 - 3 } \cline { 5 - 6 } $\mathrm{ABS} / \mathrm{RC}$ & -4.39 & $* * *$ & & -4.15 & $\mathrm{p}(\mathrm{t})$ \\
$\mathrm{TR}_{0} / \mathrm{RC}$ & -0.72 & $\mathrm{~ns}$ & & -2.84 & $* * *$ \\
$\mathrm{ET}_{0} / \mathrm{RC}$ & 15.70 & $* * *$ & & -0.17 & $* *$ \\
$\mathrm{DI}_{0} / \mathrm{RC}$ & -4.02 & $* *$ & & -2.97 & $\mathrm{~ns}$ \\
\hline
\end{tabular}


sorption $(\mathrm{ABS} / \mathrm{RC})$ and dissipation $\left(\mathrm{DI}_{0} / \mathrm{RC}\right)$ of light energy per active reaction centre were significantly higher in drought treated leaves than in control leaves of both genotypes (Fig. $4 \mathrm{~A}$ and $\mathrm{D})$. Trapping per active reaction centre $\left(\mathrm{TR}_{0} / \mathrm{RC}\right)$ shown in Fig. $4 \mathrm{~B}$ was significantly increased under drought treatment compared to control in leaves of genotype OS. By contrast, electron transport per active reaction center $\left(\mathrm{ET}_{0} / \mathrm{RC}\right)$ was significantly lowered in drought treatment leaves of genotype Kelleris 16 while the same parameter in drought treatment leaves of genotype OS remain unchanged (Fig. 4C).

Mean values and standard deviations of photosynthetic pigment concentrations in drought and control treatment leaves of genotypes Kelleris 16 and OS are shown in Tab. 4. The mean values of chlorophyll $a$ and total chlorophylls in drought-treated leaves were significantly lower than in control leaves of both investigated genotypes (Tab. 5). Drought stress did not decreased chlorophyll $b$ concentration in leaves of genotype Kelleris 16, unlike in genotype OS, while the opposite situation appeared for chlorophyll $a / b$ ratio.

Tab. 4. Mean values ( \pm standard deviation) of photosynthetic pigments concentrations on the $8^{\text {th }}$ day of the experiment in control and drought-treated leaves of genotypes Kelleris 16 and OS.

\begin{tabular}{|c|c|c|c|c|}
\hline \multirow{2}{*}{$\begin{array}{l}\text { Genotype } \\
\text { Treatment }\end{array}$} & \multicolumn{2}{|c|}{ Kelleris 16} & \multicolumn{2}{|c|}{ OS } \\
\hline & Control & Drought & Control & Drought \\
\hline Chl $a\left(\mathrm{mg} \mathrm{g}^{-1} \mathrm{DW}\right)$ & $3.72 \pm 0.23$ & $2.48 \pm 0.12$ & $2.97 \pm 0.07$ & $2.26 \pm 0.05$ \\
\hline Chl $b\left(\mathrm{mg} \mathrm{g}^{-1} \mathrm{DW}\right)$ & $1.11 \pm 0.06$ & $1.11 \pm 0.11$ & $0.97 \pm 0.04$ & $0.77 \pm 0.05$ \\
\hline $\mathrm{Chl} \mathrm{a}+b\left(\mathrm{mg} \mathrm{g}^{-1} \mathrm{DW}\right)$ & $4.83 \pm 0.25$ & $3.58 \pm 0.03$ & $3.94 \pm 0.11$ & $3.03 \pm 0.10$ \\
\hline $\mathrm{Chl} a / \mathrm{Chl} b$ & $3.35 \pm 0.20$ & $2.26 \pm 0.33$ & $3.06 \pm 0.07$ & $2.97 \pm 0.17$ \\
\hline
\end{tabular}

Tab. 5. $t$-value and the probability levels in the $t$-test for photosynthetic pigments concentrations measured on the $8^{\text {th }}$ day of the experiment in control and drought-treated leaves of genotypes Kelleris 16 and OS. Significance level is marked at $\mathrm{p} \leq 0.05(*), 0.01(* *)$ and $0.001(* * *)$. ns - no significance.

\begin{tabular}{|c|c|c|c|c|}
\hline \multirow{2}{*}{$\begin{array}{l}\text { Genotype / } \\
\text { parameter }\end{array}$} & \multicolumn{2}{|c|}{ Kelleris 16} & \multicolumn{2}{|c|}{ OS } \\
\hline & $\mathrm{t}$ & $\mathrm{p}(\mathrm{t})$ & $\mathrm{t}$ & $\mathrm{p}(\mathrm{t})$ \\
\hline Chl $a$ & 9.72 & $* * *$ & 16.27 & $* * *$ \\
\hline Chl $b$ & 0.09 & ns & 5.97 & $* * *$ \\
\hline Chl $\mathrm{a}+b$ & 9.80 & $* * *$ & 12.18 & $* * *$ \\
\hline $\mathrm{Chl} a / \mathrm{Chl} b$ & 5.61 & $* *$ & 0.97 & ns \\
\hline
\end{tabular}

\section{Discussion}

In this study we used two types of molecular markers, microsatellite markers in order to identify sour cherry genotypes (KAÇAR et al. 2006, ANTONIUs et al. 2012) and AFLP markers in order to identify genotypes within the cultivar Oblačinska (ZHOU et al. 2002, TAVAUD et al. 2004). A significant correlation $(r=0.878)$, almost identical to the correlation $(r=0.873)$ obtained by KRICHEN et al. (2010), was revealed between the results of SSR and AFLP 
markers in this investigation. Cluster analysis generated from the similarity matrix of both SSRs and AFLPs data differentiated only genotypes, but not genotypes of the cultivar Oblačinska (Fig. 1). These findings are in accordance with VENTURI et al. (2006) who showed that SSRs and AFLPs were not able to distinguish genotypes (or clones) of apple genotypes Gala and Braeburn.

Abiotic stressors, especially drought, negatively affect the growth and development of plants and reduce the productivity or fertility of plants. Plant response to the stress caused by drought is a complex biological and physico-chemical process that involves a number of micro and macro molecules (KHAKWANI et al. 2011). The study of drought influence on plant water status in association with photosynthetic parameters is important for understanding the physiological mechanisms of drought tolerance and identification of tolerant genotypes of some species (OMAE et al. 2007). Ability to retain the water during dehydration is an important strategy for plant tolerance to stress caused by drought (SÁNCHEZ-RoDRíGUEZ et al. 2010). Leaf RWC was measured in order to quantify water status in leaves of investigated genotypes. According to RWC results (Fig. 2), genotypes Kelleris 16 and OS were proven to have the opposite reaction to drought. Genotype OS revealed a higher tolerance to drought than genotype Kelleris 16 . Their photosynthetic efficiency and photosynthetic pigment contents were further investigated in order to understand the physiological mechanisms of drought tolerance.

Down-regulation of PSII photochemical efficiency caused by drought stress was manifested as a significant decrease of maximum quantum yield of PSII in drought-stressed leaves of genotype Kelleris $16,45.23 \%$ of the value in control leaves (Fig. 3A). The $F_{v} / F_{m}$ in drought-treated leaves of Kelleris 16 was 0.38 , which is much below the considered boundary value (0.75) for fully functional PSII (BOLHÁR-NORDENKAMPF et al. 1989). A reduction of $\mathrm{F}_{\mathrm{v}} / \mathrm{F}_{\mathrm{m}}$ in drought stress was reported by many authors (BAUERLE et al. 2003, BERTAMINI et al. 2007). Performance index ( $\left.\mathrm{PI}_{\mathrm{ABS}}\right)$ was decreased in drought-treated leaves of both investigated genotypes (Fig. 3B). Unlike $\mathrm{F}_{\mathrm{v}} / \mathrm{F}_{\mathrm{m}}, \mathrm{PI}_{\mathrm{ABS}}$ is much more sensitive photosynthetic parameter and it can detect stress in plants even before visible symptoms appear on the leaves

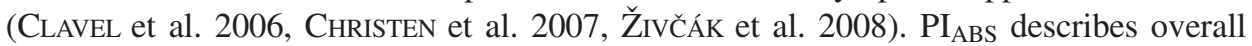
photosynthetic performance through the parameters that describe three main functional characteristics of PSII reaction centre (STRASSER et al. 2000), namely RC/ABS (density of reaction centres on chlorophyll basis), $\mathrm{TR}_{0} / \mathrm{DI}_{0}$ (ratio of trapping and dissipation fluxes) and $\mathrm{ET}_{0} /\left(\mathrm{TR}_{0}-\mathrm{ET}_{0}\right)$ (efficiency of the conversion of excitation energy to electron transport). Drought-treated leaves of genotype Kelleris 16 had all components of $\mathrm{PI}_{\mathrm{ABS}}$ significantly lowered $\left(42.55,15.79\right.$ and $34.64 \%$ of the value in control leaves for RC/ABS, $\mathrm{TR}_{0} / \mathrm{DI}_{0}$ and $\mathrm{ET}_{0} /\left(\mathrm{TR}_{0}-\mathrm{ET}_{0}\right)$, respectively) in comparison to control leaves (Tab. 1 and 2). It is very likely that drastic reduction of $\mathrm{TR}_{0} / \mathrm{DI}_{0}$ (to $15.79 \%$ of the value in control leaves) contributed the most to the decrease of photosynthetic efficiency, namely $\mathrm{PI}_{\mathrm{ABS}}$. A similar conclusion about the impact $\mathrm{TR}_{0} / \mathrm{DI}_{0}$ on $\mathrm{PI}_{\mathrm{ABS}}$ in different stress conditions was deduced by LEPEDUŠ et al. (2009) and NusSBAuM et al. (2001). They reported that the reduction of $\mathrm{TR}_{0} / \mathrm{DI}_{0}$ was significantly influenced by a large increase in energy dissipation $\left(\mathrm{DI}_{0} / \mathrm{RC}\right)$ apart from trapping of electrons per active reaction centre $\left(\mathrm{TR}_{0} / \mathrm{RC}\right)$. The same situation occurred in our investigation. In drought-treated leaves of Kelleris 16 energy dissipation per active reaction centre $\left(\mathrm{DI}_{0} / \mathrm{RC}\right)$ was significantly increased, while trapping of electrons per active reaction centre $\left(\mathrm{TR}_{0} / \mathrm{RC}\right)$ was unaffected (Fig. $\left.4 \mathrm{~B}, \mathrm{D}\right)$. 
Drastic increase of energy dissipation is a consequence of enlarged absorption (ABS/RC) in drought treatment leaves of both genotypes (Fig. 4A). Parameter ABS/RC represents the functional size of the antenna complexes respectively, provides information on the average amount of absorbing chlorophyll molecules, hence increasing this parameter indicates a reduction in the number of active reaction centres. Specifically, due to the high proton gradient through the thylakoid membranes, a portion of the active reaction centre gets a dissipation role, transforming violaksantin to zeaxanthin and thereby emitting energy in the form of heat in order to avoid oxidative damage of PSII (CRITCHLEY 2000). Equal energy flow through the photosystems in terms of increasing the $\mathrm{ABS} / \mathrm{RC}$ and $\mathrm{DI}_{0} / \mathrm{RC}$ occurs also in the stress caused by chromium (APPENROTH et al. 2001), and in phosphorus-depleted leaves (LiN et al. 2009).

The conversion of excitation energy in electron transport, i.e. parameter $\mathrm{ET}_{0} /\left(\mathrm{TR}_{0}-\mathrm{ET}_{0}\right)$, was decreased in leaves of genotype Kelleris 16 exposed to drought stress (Tab. 2). Further, electron transport beyond $\mathrm{Q}_{\mathrm{A}}{ }^{-}$expressed per active reaction centre $\left(\mathrm{ET}_{0} / \mathrm{RC}\right)$ was also significantly impaired in drought-treated leaves of genotype Kelleris 16 (Fig. 4C) due to reduced transport from $\mathrm{Q}_{\mathrm{A}}$ to $\mathrm{Q}_{\mathrm{B}}$. These results suggest that the conversion of excitation energy in electron transport caused the decrease of the $\mathrm{PI}_{\mathrm{ABS}}$ and overall photosynthetic efficiency since the connection between electron transport and $\mathrm{CO}_{2}$ fixation has been proved (KRALL and EDWARDS 1992), and thus the connection of $\mathrm{PI}_{\mathrm{ABS}}$ with $\mathrm{CO}_{2}$ fixation (VAN HEERDEN et al. 2007).

Decreased photosynthetic efficiency was not only due to changes in energy flow through the PSII but also due to decreased pigment content. Impaired content of photosynthetic pigments in leaves of drought treatment, especially chlorophyll $a$ and total chlorophylls $(a+b)$ may be due to reduced protein synthesis at the LHC complexes or destruction within complexes which, among other functions, protect the photosynthetic apparatus (KAUSER et al. 2006). Also, degradation of photosynthetic pigments can be result in oxidative damage of chloroplast lipids, pigments and proteins, particular proteins in thylakoid membranes, which leads to the degradation of PS II and consequently, reduced trapping and electron transport, as well as reduced production of ATP and NADPH, and and ultimately reduced CO2 fixation (ABDALLA and EL-KoshIBAN 2007). Reduced chlorophylls ratio $(a / b)$ indicates that the antenna complexes of PSII were increased allowing increased absorption of photons, leading to excess of the electrons in PSII and to the modification of the active reaction centres in dissipative (LEPEDUŠ et al. 2009).

From the presented results, it can be concluded that photosynthesis was down-regulated in leaves of the genotype Kelleris 16 exposed to drought, while genotype OS appears to be more tolerant. An indication of impaired photosynthetic efficiency in leaves of genotype Kelleris 16 was found in reduced photosynthetic pigment contents. Changes of antenna complexes in PSII, seen as decreased chlorophylls ratio $(a / b)$, altogether with decreased total chlorophylls content $(a+b)$, indicate the adaptation of PSII to drought conditions. Overall photosynthetic performance expressed as $\mathrm{PI}_{\mathrm{ABS}}$ was down-regulated in both investigated genotypes, although maximum quantum yield of PSII remained unchanged in drought-treated leaves of genotype OS. However, decrement of $\mathrm{PI}_{\mathrm{ABS}}$ was much more pronounced in genotype Kelleris 16 mainly because of changes in a certain fraction of RCs which become dissipative centres, seen as an increase in $\mathrm{ABS} / \mathrm{RC}$ and $\mathrm{DI}_{0} / \mathrm{RC}$, in order to avoid photooxidative damage of photosynthetic apparatus. Also, energy flow through the PSII i.e. 
electron transport was impaired, seen as a decrease in $\mathrm{ET}_{0} /\left(\mathrm{TR}_{0}-\mathrm{ET}_{0}\right)$ and $\mathrm{ET}_{0} / \mathrm{RC}$, which leads to depleted $\mathrm{CO}_{2}$ fixation and photosynthesis according to KRALL and EDWARDS (1992). The described changes in the functioning of photosynthetic apparatus in drought-treated plants of Kelleris 16 are the main distinction between the two investigated genotypes regarding the drought adaptation mechanisms of photosynthesis.

\section{Acknowledgments}

This work was supported by the scientific research grants to Z. J. (research agreement 073-1781844-1930) and H. L. (research agreement 073-0731674-1673), all funded by the Ministry of Science, Education and Sports of the Republic of Croatia.

\section{References}

Abdalla, M. M., EL-KhoshiBAn, N. H., 2007: The influence of water stress on growth, relative water content, photosynthetic pigments, some metabolic and hormonal contents of two Triticum aestivum genotypes. Journal of Applied Sciences Research 3, 2062-2074.

Antonius, K., Aaltonen, M., Uosukainen, M., Hurme, T., 2012: Genotypic and phenotypic diversity in Finnish cultivated sour cherry (Prunus cerasus L.). Genetic Resources and Crop Evolution 59, 375-388.

Appenroth, K.-J., StÖckel, J., Srivastava, A., Strasser, R. J., 2001: Multiple effects of chromate on the photosynthetic apparatus of Spirodela polyrhiza as probed by OJIP chlorophyll a fluorescence measurements. Environmental Pollution 115, 49-64.

Bauerle, W. L., Duduley, J. B., Grimes, L. W., 2003: Genotypic variability in photosynthesis, water use, and light absorption among red and Freeman maple genotypes in response to drought stress. Journal of American Society for Horticultural Science 128, 337-342.

Bertamini, M., Zulini, L., Zorer, R., Muthuchelian, K., Nedunchezhian, N., 2007: Photoinhibition of photosynthesis in water deficit leaves of grapevine (Vitis vinifera L.) plants. Photosynthetica 45, 426-432.

Bolhár-Nordenkampf, H. R., Long, S. P., Baker, N. R., Öuquist, G., Schreiber, U., LECHNER, E. G., 1989: Chlorophyll fluorescence as a probe of the photosynthetic competence of leaves in the field: A Review of Current Instrumentation. Functional Ecology 3, 497-514.

Cantini, C., Iezzoni, A. F., Lamboy, W. F., Boritzki, M., Struss, D., 2001: DNA fingerprinting of tetraploid cherry germplasm using simple sequence repeats. Journal of the American Society for Horticultural Science 126, 205-209.

Cesar, V., Štolfa, I., Maurović, S., PAraĐiković, N., LePeduš, H., 2008: Differential appearance of vacuolar polyphenols in Black pine (Pinus nigra) needles in response to the lowering of $\mathrm{SO}_{2}$ in the air. Acta Botanica Hungarica 50, 326-335.

Christen, D., Schönmann, S., Jermini, M., Strasser, R. J., Dfago, G., 2007: Characterisation and early detection of grapevine (Vitis vinifera) stress responses to esca disease by in situ chlorophyll fluorescence and comparison with drought stress. Environmental and Experimental Botany 60, 504-514. 
Clarke, J. B., Tobutt, K. R., 2003: Development and characterisation of polymorphic microsatellites from Prunus avium »Napoleon«. Molecular Ecology Notes 3, 578-580.

Clavel, D., Diouf, O., Khalfaoui, J. L., Braconnier, S., 2006: Genotypes variation in fluorescence parameters among closely related groundnut (Arachis hypogaea L.) lines and their potential for drought screening programs. Field Crop Research 96, 296-306.

Critchley, C., 2000: Photoinhibition. In: Raghavendra, A. S. (ed.), Photosynthesis: a comprehensive treatise, 264-272. Cambridge University Press, Cambridge.

DiCE, L. R., 1945: Measures and amount of ecologic association between species. Ecology 26, 297-302.

Dirlewanger, E., Cosson, P., Tavaud, M., Aranzana, M. J., Poizat, C., Zanetto, A., Arús, P., LAIgret, F., 2002: Development of microsatellite markers in peach [Prunus persica (L.) Batsch] and their use in genetic analysis in peach and sweet cherry (Prunus avium L.). Theoretical and Applied Genetics 105, 127-138.

Doyle, J. J., Doyle, J. L., 1987: Isolation of plant DNA from fresh tissue. Phytochemical Bulletin 19, 11.

Fao Statistical Databases, 2011: Food and Agriculture Organisation of the United Nations, Rome, Italy.

ForCE, L., CRITCHLEy, C., VAN RENSEN, J. S., 2003: New fluorescence parameters for monitoring photosynthesis in plants. Photosynthesis Research 78, 17-23.

Hassanzadeh, M., Ebadi, A., Panahyan-e-Kivi, M., Eshghi, A. G., Jamaati-e-Somarin, S., SAEIDI, M., ZABIHI-E-MAHMOODABAD, R., 2009: Evaluation of drought stress on relative water content and chlorophyll content of sesame (Sesamum indicum L.) genotypes at early flowering stage. Research Journal of Environmental Sciences 3, 345-350.

HormazA, J. I., 2002: Molecular characterization and similarity relationships among apricot (Prunus armeniaca L.) genotypes using simple sequence repeats. Theoretical and Applied Genetics 104, 321-328.

Jaleel, C. A., Manivannan, P., Wahidi, A., Ferooq, M., Jasim Al-Juburi, H., SomaSUNDARAM, R., PANNERSElVAM, R., 2009: Drought stress in plants: a review on morphological characteristics and pigments composition. International Journal of Agriculture and Biology 11, 100-105.

KaÇar, Y. A., Cetiner, M. S., Cantini, C., Iezzoni, A. F., 2006: Simple sequence repeat (SSR) markers differentiate Turkish sour cherry germplasm. Journal of American Pomological Society 60, 136-143.

Kauser, R., Athar, H.-U.-R., Ashraf, M., 2006: Chlorophyll fluorescence: a potential indicator for rapid assessment of water stress tolerance in canola (Brassica napus L.). Pakistan Journal of Botany 38, 1501-1509.

Khakwani, A. A., DennetT, M. D., Munir, M., 2011: Drought tolerance screening of wheat varieties by inducing water stress conditions. Songklanakarin Journal of Science and Technology 33, 135-142.

Krall, J. P., EDWARDS, G. E., 1992: Relationship between photosystem II activity and $\mathrm{CO}_{2}$ fixation in leaves. Physiologia Plantarum 86, 180-187. 
Viljevac M., Dugalić K., Mihaljević I., Šimić D., Sudar R., Jurković Z., LePeduš H.

Krichen, L., Bourguiba, H., Audergon, J. C., Trifi-Farah, N., 2010: Comparative analysis of genetic diversity in Tunisian apricot germplasm using AFLP and SSR marker. Scientia Horticulturae 127, 54-63.

Lepeduš, H., Tomašić, A., Jurić, S., Katanić, Z., Cesar, V., Fulgosi, H., 2009: Photochemistry of PSII in CYP38 Arabidopsis thaliana deletion mutation. Food Technology and Biotechnology 47, 275-280.

LichtenthaleR, H. K., 1987: Chlorophyll and carotenoids: pigments of photosynthetic biomembranes. Methods in Enzymology 148, 350-382.

Lin, Z.-H., Chen, L.-S., Chen, R.-B., Zhang, F.-Z., JiAng, H.-X., TANG, N., 2009: $\mathrm{CO}_{2}$ assimilation, ribulose-1,5-bisphosphate carboxylase/oxygenase, carbohydrates and photosynthetic electron transport probed by the JIP-test, of tea leaves in response to phosphorus supply. BMC Biology 9, 43.

MANTEL, N., 1967: The detection of disease clustering and a generalized regression approach. Cancer Research 27, 209-220.

MAXwell, K., Johnson, G. N., 2000: Chlorophyll fluorescence - a practical guide. Journal of Experimental Botany 51, 659-662.

Nussbaum, S., Geismann, M., Eggenberg, P., Strasser, R. J., Fuhrer, J., 2001: Ozone sensitivity in herbaceous species as assessed by direct and modulated chlorophyll fluorescence techniques. Journal of Plant Physiology 158, 757-766.

Omae, H., Kumar, A., Kashiwaba, K., Shono, M., 2007: Assessing drought tolerance of snap bean (Phaseolus vulgaris) from genotypic differences in leaf water relations, shoot growth and photosynthetic parameters. Plant Production Science 10, 28-35.

Pedersen B. H., 2006: DNA fingerprints of 51 sweet and sour Prunus accessions using simple sequence repeats. Journal of Horticultural Science and Biotechnology 81, 118-124.

Pedisić, S., Dragović-Uzelac, V., LeVAJ, B., ŠKeVin, D., 2010: Effect of maturity and geographical region on anthocyanin content of sour cherries (Prunus cerasus var. marasca). Food Technology and Biotechnology 48, 86-93.

PUŠKAR, B., 2005: Intravarietal variabilty of Oblačinska cherry (In Croatian). PhD. Thesis, University of Zagreb.

Rampino, P., Pataleo, S., Gerardi, C., Giovanni, M., Perrotta, C., 2006: Drought stress response in wheat: physiological and molecular analysis of resistant and sensitive genotypes. Plant Cell and Environment 29, 2143-2152.

Rosales-Serna, R., Kohashi-Shibata, Acosta-Gallegos, J. A., Trejo-López, C., Ortiz-CERECERES, J., KelLy, J. D., 2004: Biomass distribution, maturity acceleration and yield in drought stress common bean genotypes. Field Crops Research 85, 203-211.

Sánchez-Rodríguez, E., Rubio-Wilhelmi, M., Cervilla, L. M., Blasco, B., Rios, J. J., Rosales, M. A., Romero, L., RuIz, J. M., 2010: Genotypic differences in some physiological parameters symptomatic for oxidative stress under moderate drought in tomato plants. Plant Science 178, 30-40.

Strasser, R. J., Srivastava, A., Tsimilli-Michael, M., 2000: The fluorescent transient as a tool to characterise and screen photosynthetic samples. In: Yunus, M., Pathre, U., Mohanty, P., (eds.), Probing photosynthesis: mechanisms, regulation and adaptation, 445-483. Taylor and Francis, London. 
Strasser, R. J., Srivastava, A., Tsimilli-Michael, M., 2004: Analysis of chlorophyll a fluorescence transient. In: PAPAgeorgiou, G. C., GovindjeE (eds.), Chlorophyll $a$ fluorescence: A signature of photosynthesis. Advances in Photosynthesis and Respiration 19, 321-362. Kluwer Academic Publishers, Rotterdam.

Tavaud, M., Zaneto, A., David, J. L., Laigret, F., Dirlewanger, E., 2004: Genetic relationship between diploid and allotetraploid cherry species (Prunus avium, Prunus $\times$ gondouinii and Prunus cerasus). Heredity 93, 631-638.

van Heerden, P. D. R., Swanepoel, J. W., KrÜGer, G. H. J., 2007: Modulation of photosynthesis by drought in two desert scrub species exhibiting $\mathrm{C}_{3}$-mode $\mathrm{CO}_{2}$ assimilation. Environmental and Experimental Botany 61, 124-136.

Venturi, S., Dondini, L., Donini, P., SANSAVINI, S., 2006: Retrotransposon characterisation and fingerprinting of apple clones by S-SAP markers. Theoretical and Applied Genetics 112, 440-444.

Vos, P., Hogers, R., Bleeker, M., Reijans, M., van de Lee, T., Hornes, M., Frijters, A., Pot, J., Peleman, J., KuiPer, M., Zabeau, M., 1995: AFLP: a new technique for DNA fingerprinting. Nucleic Acids Research 23, 4407-4414.

Zhou, L., Kappel, F., Hampson, C., Wiersma, P. A., Bakkeren, G., 2002: Genetic analysis and discrimination of sweet cherry genotypes and selection using amplified fragment length polymorphism fingerprints. Journal of the American Society for Horticultural Science 127, 786-792.

ŽIvČÁK, M., Brestič, M., OlšOVSKÁ, K., SlamkA, P., 2008: Performance index as a sensitive indicator of water stress in Triticum aestivum L. Plant Soil and Environment 54, 133-139. 